\title{
Political instability and inflation volatility
}

\author{
Ari Aisen · Francisco José Veiga
}

Received: 13 March 2007 / Accepted: 30 October 2007 / Published online: 17 November 2007

(C) Springer Science+Business Media, LLC. 2007

\begin{abstract}
The purpose of this paper is to empirically analyze the effects of political instability, social polarization and the quality of institutions on inflation volatility over time and across countries. Using the system-GMM estimator for linear dynamic panel data models on a sample covering 160 countries, analyzed in the period from 1960 to 1999, this paper finds that higher degrees of political instability and social polarization, less democracy, and lower de facto central bank independence are associated with more volatile inflation rates. Furthermore, political instability has greater effects on inflation volatility in developing countries with lower degrees of central bank independence and economic freedom.
\end{abstract}

Keywords Inflation · Volatility · Political instability · Institutions

JEL Classification E31 $\cdot$ E63

\section{Introduction}

Economists generally recognize that high and volatile inflation is harmful to society's welfare. This realization had a strong impact on the profession, leading scholars to devote great effort to fully comprehending the inflationary process so as to achieve price stability. However, few studies focused on disentangling the effects of high inflation levels from those of high inflation volatility on welfare and growth. This is because higher inflation levels are typically associated with higher inflation volatility. ${ }^{1}$ Friedman (1977) attempted to shed

\footnotetext{
${ }^{1}$ For a descriptive analysis showing a high correlation between inflation levels and volatility, see Fischer et al. (2002).
}

The views expressed in this paper are those of the authors and do not necessarily represent those of the IMF or IMF policy.

A. Aisen

International Monetary Fund, Asia and Pacific Department, 700 19th Street NW, Washington, DC 20431, USA 
some light on the controversy, conjecturing that growing inflation volatility would render the economy less efficient by introducing frictions on markets, and creating a wedge between relative prices prevailing in the economy and those which would have been determined solely by market forces in the absence of inflation volatility. This suggests that high inflation volatility may be more disruptive to the economy than high inflation levels. While studies on the determinants of inflation are abundant in the literature, scholars have not yet extensively investigated the causes of inflation volatility—surprisingly so, given its ill effects on growth. ${ }^{2}$

Cukierman et al. (1992) find that central bank independence reduces inflation volatility. Some studies have related inflation volatility to other variables. Bleaney and Fielding (2002) find that developing countries with pegged exchange rates have lower inflation levels and volatility. Granato et al. (2006) and Bowdler and Malik (2005) find that trade openness can reduce inflation volatility. In another study, Rother (2004) concludes that volatility in discretionary fiscal policies has contributed to inflation volatility in a panel of 15 OECD countries for a period of 35 years. However, this result does not shed light on the deep determinants of inflation volatility.

Why do some countries have more volatile monetary and fiscal policies than others? This paper argues that an important part of the answer may lie in the effects of political and institutional factors, as politically unstable and socially polarized countries with weak institutions are often susceptible to political shocks leading to discontinuous monetary and fiscal policies which result in higher inflation volatility. ${ }^{3}$ In line with Cukierman et al. (1992), Acemoglu et al. (2003), and Aisen and Veiga (2005, 2006), we hypothesize that political and institutional factors have a direct impact on inflation volatility which goes beyond their indirect effects through inflation levels. Moreover, we argue that central bank independence and economic freedom play a vital role in stemming the negative effects of political instability on inflation volatility. This hypothesis is consistent with the increase in operational and political autonomy of central banks observed in developing countries (Armone et al. 2006). Greater central bank independence protects monetary policy from the influence of fiscal authorities which may be susceptible to lobbying and political pressures prevalent in politically unstable and socially polarized countries. This hypothesis is also in line with Rogoff (1985), who argues in favor of delegating monetary policy to a weight-conservative central banker to avoid time-inconsistency problems of monetary policy and reduce inflation levels and volatility. Similarly, greater economic freedom reduces the scope for government intervention in the economy, discouraging rent-seeking behavior and lobbying, while promoting fiscal discipline.

Using a panel dataset covering more than 100 countries from 1960 to 1999, we clearly show that higher degrees of political instability and social polarization, less democracy, and lower de facto central bank independence lead to higher inflation volatility. We also show that political instability has a larger impact on inflation volatility in developing countries with lower degrees of central bank independence and economic freedom. These results reveal the essential role played by strong institutions (such as central bank independence)

\footnotetext{
${ }^{2}$ For recent studies which present evidence of the negative impact of inflation levels and/or volatility on growth, see Barro and Sala-i-Martin (2004, Chap. 12), Edison et al. (2002), Elder (2004), and Fatás and Mihov (2005). But, it is worth noting that there is no widespread consensus on the relationship between inflation and long-run economic growth. In fact, according to the survey of Temple (2000) the empirical evidence of that relationship is mixed, and in Sala-i-Martin et al. (2004) average inflation is not a robust determinant of long-term growth.

${ }^{3}$ Woo (2003) shows that political instability and weak institutions are among the determinants of public deficits.
} 
in deflecting the potential negative effects of political instability. While Aisen and Veiga $(2005,2006)$ focused on the political, institutional and economic determinants of inflation and seigniorage, this paper contributes to the literature by emphasizing the interaction between political and institutional variables in the determination of inflation volatility.

The remainder of this paper is structured as follows: Sect. 2 describes the data and the econometric models, Sect. 3 presents the empirical results, and Sect. 4 concludes the paper.

\section{Data and the empirical models}

Annual data on economic, political and institutional variables, from 1960 to 1999 were gathered for 178 countries, but missing values for several variables reduce the number of countries in the estimations to at most 160 . The sources of economic data were the International Monetary Fund's International Financial Statistics (IFS), the Penn World Tables-Mark 6.1 (PWT), the World Bank's World Development Indicators (WDI) and Global Development Network Growth Database (GDN), and Levy-Yeyati and Sturzenegger (2003). Political and institutional data were obtained from the Cross National Time Series Data Archive (CNTS); the Polity IV Database, the State Failure Task Force Database (SFTF), Cukierman et al. (1992), Sturm and de Haan (2001), and Gwartney and Lawson (2002).

The hypothesis that political instability and other political and institutional variables affect inflation volatility is tested by estimating dynamic panel data models for standard deviations of inflation (taken from the IFS) for consecutive, non-overlapping, 3-year periods, from 1960 to $1999 .{ }^{4}$ Since standard deviations of inflation have very high variability, their $\operatorname{logarithms,~} \log [S D$ (Inflation)], were used as our dependent variable. Our baseline model includes the following explanatory variables:

- Lagged logarithm of inflation volatility (IFS), L.Log[SD(Inflation)]. Since this variable accounts for the inertia that may exist in inflation volatility, a positive coefficient is expected.

- $\log ($ Inflation): Logarithm of the inflation rate (IFS). According to Fischer et al. (2002), there is a strong positive relationship between inflation levels and volatility. Thus, a positive coefficient is expected.

- Cabinet changes (CNTS): counts the number of times in a year in which a new premier is named and/or $50 \%$ of the cabinet posts are occupied by new ministers. Aisen and Veiga (2006) showed that political instability leads to higher inflation, which implies that it indirectly affects inflation volatility. By including cabinet changes in the model, along with $\log$ inflation, we test the hypothesis that ministerial turnover also has a direct effect on inflation volatility (beyond the indirect one that operates through inflation rates). A positive coefficient is expected, as greater political instability leads to more unstable economic policies and, consequently, to greater inflation volatility.

- Ethnic Homogeneity Index (SFTF): ranges from 0 to 1 , with higher values indicating ethnic homogeneity, and equals the sum of the squared population fractions of the seven largest ethnic groups in a country. For each year, it takes the value of the index in the beginning of the respective decade. According to Woo (2003) higher social polarization, which can be proxied by ethnic heterogeneity, leads to greater disparity in preferences

\footnotetext{
${ }^{4}$ The periods are: 1960-62, 1963-65, .., 1993-95, and 1996-99 (the last period is 4-years long). The mean of the data is constant over the period for which the standard deviation is calculated. In robustness tests, alternative period lengths are used.
} 
for different types of government spending and public deficits. Aisen and Veiga (2005) showed that it leads to higher seigniorage. Consequently, greater ethnic homogeneity should lead to lower inflation rates. Here, we test the hypothesis that it also affects inflation volatility directly. A negative coefficient is expected.

- Polity Scale (Polity IV): from strongly autocratic (-10) to strongly democratic (10). According to Aisen and Veiga (2006), democracy is associated with lower inflation rates. In this model we test the hypothesis that it is also directly associated with lower inflation volatility. A negative coefficient is expected.

The empirical model for inflation volatility can be summarized as follows:

$$
\begin{aligned}
\log [S D(\operatorname{Inf})]_{i t}= & \alpha \log [S D(\operatorname{Inf})]_{i, t-1}+\beta \log (\operatorname{Inf})_{i t}+\delta C C_{i, t}+\gamma E H I_{i t}+\lambda P S_{i t} \\
& +v_{i}+\varepsilon_{i t}, \quad i=1, \ldots, N, t=1, \ldots, T_{i},
\end{aligned}
$$

where $\log [S D(\operatorname{Inf})]_{i t}$ stands for the logarithm of the standard deviation of inflation of country $i$ for the 3-year period $t, \log (\operatorname{Inf})$ for the logarithm of its inflation rate, $C C$ for Cabinet Changes, EHI for the Ethnic Homogeneity Index, and PS for the Polity Scale; $\alpha, \beta, \delta, \gamma$ and $\lambda$ are the parameters to be estimated, $v$ are country-specific effects, and, $\varepsilon$ is the error term. It is possible that other variables that have been found to affect inflation levels also affect inflation volatility directly. This possibility will be accounted for in robustness tests that add other explanatory variables to this model. Descriptive statistics of the variables included in the tables of results are shown in Table 1.

One problem of estimating this model using OLS is that $\log [S D(\operatorname{Inf})]_{i, t-1}$ (the lagged dependent variable) is endogenous to the fixed effects $\left(v_{i}\right)$, which gives rise to "dynamic panel bias". Thus, OLS estimates of this baseline model will be inconsistent, even in the fixed or random effects settings, because $\log [S D(\operatorname{Inf})]_{i, t-1}$ would be correlated with the error term, $\varepsilon_{i t}$, even if the latter is not serially correlated. ${ }^{5}$ If the number of time periods available $(T)$ were large, the bias would become very small and the problem would disappear. But, since our sample has only 13 non-overlapping 3-year periods, the bias may still be important. ${ }^{6}$ First-differencing (1) removes the individual effects $\left(v_{i}\right)$ and thus eliminates a potential source of bias:

$$
\begin{aligned}
D \cdot \log [S D(\operatorname{Inf})]_{i t}= & \alpha D \cdot \log [S D(\text { Inf })]_{i, t-1}+\beta D \cdot \log (\text { Inf })_{i t}+\delta D \cdot C C_{i, t}+\gamma D \cdot E H I_{i t} \\
& +\lambda D \cdot P S_{i t}+D \cdot \varepsilon_{i t}, \quad i=1, \ldots, N t=1, \ldots, T_{i} .
\end{aligned}
$$

But, when variables that are not strictly exogenous are first-differenced, they become endogenous, since the first difference will be correlated with the error term. Following HoltzEakin et al. (1988), Arellano and Bond (1991) developed a Generalized Method of Moments (GMM) estimator for linear dynamic panel data models that solves this problem by instrumenting the differenced predetermined and endogenous variables with their available lags in levels: levels of the dependent and endogenous variables, lagged two or more periods; levels of the pre-determined variables, lagged one or more periods. The exogenous variables can be used as their own instruments.

A problem of this difference-GMM estimator is that lagged levels are weak instruments for first-differences if the series are very persistent (see Blundell and Bond 1998). According

\footnotetext{
${ }^{5}$ See Arellano and Bond (1991) and Baltagi (2001).

${ }^{6}$ According to the simulations performed by Judson and Owen (1999), there is still a bias of $20 \%$ in the coefficient of interest for $T=30$.
} 
Table 1 Descriptive statistics

\begin{tabular}{lrrrrrl}
\hline Variable & Observ. & Mean & Std. dev. & Minimum & Maximum & Source \\
\hline Log[SD(Inflation)] & 1503 & 1.19 & 1.45 & -4.28 & 9.47 & IFS-IMF \\
Log(Inflation) & 1505 & 2.10 & 1.35 & -4.21 & 9.08 & IFS-IMF \\
Cabinet Changes & 1863 & 0.45 & 0.43 & 0.00 & 3.67 & CNTS \\
Ethnic Homogeneity Index & 1590 & 0.58 & 0.28 & 0.00 & 1.00 & SFTF \\
Polity Scale & 1702 & -0.10 & 7.53 & -10.00 & 10.00 & Polity IV \\
Legal Index of Central Bank & 653 & 0.35 & 0.12 & 0.09 & 0.69 & CWN \\
Independence & & & & & & \\
Turnover Rate & 664 & 0.24 & 0.21 & 0.00 & 1.08 & CWN \\
Updated Turnover Rate & 1064 & 0.23 & 0.21 & 0.00 & 1.10 & CWN+SdH \\
Index of Economic Freedom & 956 & 5.63 & 1.18 & 2.47 & 8.93 & EFW \\
Log(Real GDP per capita) & 1627 & 8.16 & 1.04 & 5.69 & 10.56 & PWT \\
SD(GDPpc growth) & 1582 & 4.44 & 4.59 & 0.03 & 51.41 & PWT \\
SD(GDP growth of trading partners) & 1757 & 1.19 & 0.81 & 0.01 & 7.39 & GDN-WB \\
SD (Real Overvaluation) & 1180 & 11.74 & 92.07 & 0.00 & 3082.55 & GDN-WB \\
SD(change in oil prices) & 2314 & 12.71 & 13.65 & 0.17 & 39.95 & IFS-IMF \\
US Treasury Bill Rate & 2314 & 6.04 & 2.26 & 2.70 & 11.14 & IFS-IMF \\
Exchange Rate Regime & 1132 & 4.09 & 1.12 & 1.00 & 5.00 & LYS \\
Log[Trade (\% GDP)] & 1709 & 4.06 & 0.66 & 0.91 & 5.99 & WDI-WB \\
Log[SD(Growth of M2)] & 1606 & 2.33 & 1.27 & -1.71 & 9.16 & IFS-IMF \\
Government Crises & 1829 & 0.18 & 0.37 & 0.00 & 3.00 & CNTS \\
Political Instability Index 1 & 1824 & -0.01 & 0.99 & -0.61 & 7.77 & PCA \\
Political Instability Index 2 & 1818 & -0.03 & 1.14 & -0.99 & 9.57 & PCA \\
Political Instability Index 3 & 1818 & -0.05 & 0.91 & -0.89 & 6.33 & PCA \\
\hline & & & & & &
\end{tabular}

Sources:

CNTS: Cross-National Time Series database;

CWN: Cukierman et al. (1992);

EFW: Gwartney and Lawson (2002);

GDN-WB: Global Development Network Growth Database-World Bank;

IFS-IMF: International Financial Statistics-International Monetary Fund;

LYS: Levy-Yeyati and Sturzenegger (2003);

PCA: Data generated by Principal Components Analysis on variables from CNTS;

Polity IV: Polity IV database;

PWT: Penn World Tables (Mark 6.1);

SdH: Sturm and de Haan (2001);

SFTF: State Failure Task Force database;

WDI-WB: World Development Indicators-World Bank

to Arellano and Bover (1995), efficiency can be increased by adding the original equation in levels to the system. If the first-differences of an explanatory variable are not correlated with the individual effects, lagged values of the first-differences can be used as instruments in the equation in levels. Lagged differences of the dependent variable may also be valid instruments for the levels equations.

\section{Empirical results}

The results of system-GMM estimations of our baseline model for a sample comprising 160 countries, with annual data from 1960 to 1999, are shown in Table 2. The model of 
Table 2 Inflation volatility for 3-year periods

\begin{tabular}{|c|c|c|c|c|}
\hline $\log [\mathrm{SD}$ (Inflation) $]$ & 1 & 2 & 3 & 4 \\
\hline $\log [\operatorname{SD}($ Inflation $)](-1)$ & $\begin{array}{l}.073 \\
(1.97)^{* *}\end{array}$ & $\begin{array}{l}.029 \\
(.79)\end{array}$ & $\begin{array}{l}.021 \\
(.60)\end{array}$ & $\begin{array}{l}.008 \\
(.23)\end{array}$ \\
\hline Log(Inflation) & $\begin{array}{l}.806 \\
(15.29)^{* * *}\end{array}$ & $\begin{array}{l}.824 \\
(15.29)^{* * *}\end{array}$ & $\begin{array}{l}.944 \\
(13.90)^{* * *}\end{array}$ & $\begin{array}{l}.949 \\
(14.50)^{* * *}\end{array}$ \\
\hline Cabinet Changes & $\begin{array}{l}.804 \\
(3.10)^{* * *}\end{array}$ & $\begin{array}{l}.792 \\
(3.38)^{* * *}\end{array}$ & $\begin{array}{l}.547 \\
(2.65)^{* * *}\end{array}$ & $\begin{array}{l}.529 \\
(2.19)^{* *}\end{array}$ \\
\hline Ethnic Homogeneity Index & & $\begin{array}{l}-.380 \\
(-2.59)^{* * *}\end{array}$ & $\begin{array}{l}-.374 \\
(-2.72)^{* * *}\end{array}$ & $\begin{array}{l}-.314 \\
(-1.96)^{* *}\end{array}$ \\
\hline Polity Scale & & $\begin{array}{l}-.020 \\
(-3.74)^{* * *}\end{array}$ & $\begin{array}{l}-.021 \\
(-3.93)^{* * *}\end{array}$ & $\begin{array}{l}-.021 \\
(-3.68)^{* * *}\end{array}$ \\
\hline Time & & & & $\begin{array}{l}-.217 \\
(-3.83)^{* * *}\end{array}$ \\
\hline Time $^{2}$ & & & & $\begin{array}{l}.013 \\
(3.65)^{* * *}\end{array}$ \\
\hline \# Observations & 1275 & 1070 & 1070 & 1070 \\
\hline \# Countries & 160 & 135 & 135 & 135 \\
\hline Sargan test ( $p$-value) & .173 & .378 & .234 & .356 \\
\hline
\end{tabular}

Sources: See Table 1

Notes: - System-GMM estimations for dynamic panel-data models. Sample period: 1960-1999;

- The dependent variable, $\log ($ Inflation) and Cabinet Changes were treated as endogenous. Their lagged values two and three periods were used as instruments in the first-difference equations and their once lagged first-differences were used in the levels equation;

- In column 3, dummies for 3-year periods where included in the estimations;

- Two-step results using robust standard errors corrected for finite samples (using Windmeijer's, 2005, correction).

- $t$-statistics are in parenthesis. Significance level at which the null hypothesis is rejected: ${ }^{* *}, 1 \%$; **, $5 \%$, and *, $10 \%$;

- Second order autocorrelation of residuals is always rejected

column 1 is a reduced version which includes only the first lag of the dependent variable ( $\log$ of inflation volatility), the $\log$ of the inflation rate, and cabinet changes. Although we do not expect inflation levels to be affected by contemporaneous inflation volatility, Aisen and Veiga (2006) showed that they are affected by Cabinet Changes. The latter can be affected by inflation levels and volatility, as these will surely reduce the government's popularity and increase political instability. Thus, $\log$ (Inflation) and Cabinet Changes were treated as endogenous. ${ }^{7}$

\footnotetext{
${ }^{7}$ As done for the lagged dependent variable, their lagged values two and three periods were used as instruments in the first-differenced equations and their once-lagged first-differences were used in the levels equation.
} 
All variables are statistically significant and have positive signs, as expected. Thus, there is evidence of inertia in inflation volatility, although small, as the estimated coefficient is only 0.073 . The results also indicate that there is a strong positive relationship between inflation levels and volatility (the coefficient for log inflation is 0.806 ), as found in previous studies (e.g., Fischer et al. 2002). Finally, the hypothesis that Cabinet Changes, our proxy for political instability, affect inflation volatility directly, and not only though inflation levels, is clearly supported by our results. Furthermore, the effects are sizeable: an additional cabinet change directly increases the standard deviation of inflation by a factor of about $2.23 \approx$ $\exp (0.804)$, that is by $123 \% .^{8}$

Column 2 shows the results of the estimation of the complete baseline model. Adding the Ethnic Homogeneity Index and the Polity Scale ${ }^{9}$ did not change the results concerning $\log ($ Inflation) and Cabinet Changes, but the first lag of inflation volatility is no longer statistically significant. ${ }^{10}$ Furthermore, due to missing values, 205 observations were lost and the number of countries dropped from 160 to 135 . The two additional variables are highly statistically significant and have negative signs, as expected. A one-point increase in the Index of Ethnic Homogeneity (lower social polarization) reduces inflation volatility by a factor of $1.46 \approx \exp (0.38)$, that is by $46 \%$, while one point up the Polity Scale (greater democracy) reduces it by $2 \%$, in a way that goes beyond its effects through inflation levels. ${ }^{11}$ The results for our baseline model are practically the same when time effects are taken into account. Dummy variables for 3-year periods were included in the model of column 3, and a quadratic time trend was considered in that of column 4 . In both cases, the results are very similar to those shown in column 2.

The estimations whose results are presented in Table 3 test the hypothesis that greater independence of the central bank leads to lower volatility of inflation. In column 1, we added to the baseline model the Cukierman et al. (1992) legal index of central bank independence (CBI), and, in column 2, we replaced it with the de facto index, the Turnover Rate of central bank presidents. ${ }^{12}$ The results indicate that a higher turnover rate (lower de facto independence) leads to higher inflation volatility, while legal independence seems to have no effects. ${ }^{13}$ When the Turnover Rate is interacted with dummy variables for industrial and developing countries (see column 3 ), the results indicate that higher turnover rates only lead

\footnotetext{
${ }^{8}$ The estimated indirect effect of cabinet changes is much smaller, although by no means negligible. According to Aisen and Veiga (2006), an additional cabinet change increases the inflation rate by $9.1 \%$. Given that in our model of column 1 , inflation has an estimated coefficient of 0.806 , an additional cabinet change would indirectly (through the inflation rate) increase inflation volatility by about $7.3 \% \approx(9.1 \% \times 0.806)$.

${ }^{9}$ These two variables were treated as exogenous, as they are not affected by current inflation volatility.

${ }^{10}$ Since inflation volatility exhibited inertia in the model of column 1 , for which there was a larger number of observations and countries, we preferred to keep the lag of the dependent variable in the model, even though it is no longer statistically significant. As will be shown in column 1 of Table 6 , the results for a static model are essentially the same.

${ }^{11}$ Although the effect of social polarization seems much larger than that of democracy, a one standard deviation increase in the Index of Ethnic Homogeneity reduces inflation volatility by about $12.9 \% \approx(0.28 \times 46 \%)$, while a one standard deviation rise in the Polity Scale reduces it by $15 \% \approx(7.53 \times 2 \%)$. Thus, the impact of these variables on inflation volatility is somewhat similar.

${ }^{12}$ The Cukierman et al. (1992) indexes of legal and de facto central bank independence (CBI) are the most widely used in the literature. They are also the ones with the greatest coverage in terms of countries and time period. For a description of available indexes of CBI, see Armone et al. (2006).

${ }^{13}$ The index of perceived central bank independence developed by Fry et al. (2000) is not statistically significant when included. Since it is based on a survey conducted in 1999, we can assume that it represents CBI in the 1990s, but no data is available for previous decades. It is possible that the lack of statistical significance of this index of $\mathrm{CBI}$ is due to the low number of observations available.
} 
Table 3 Inflation volatility and central bank independence

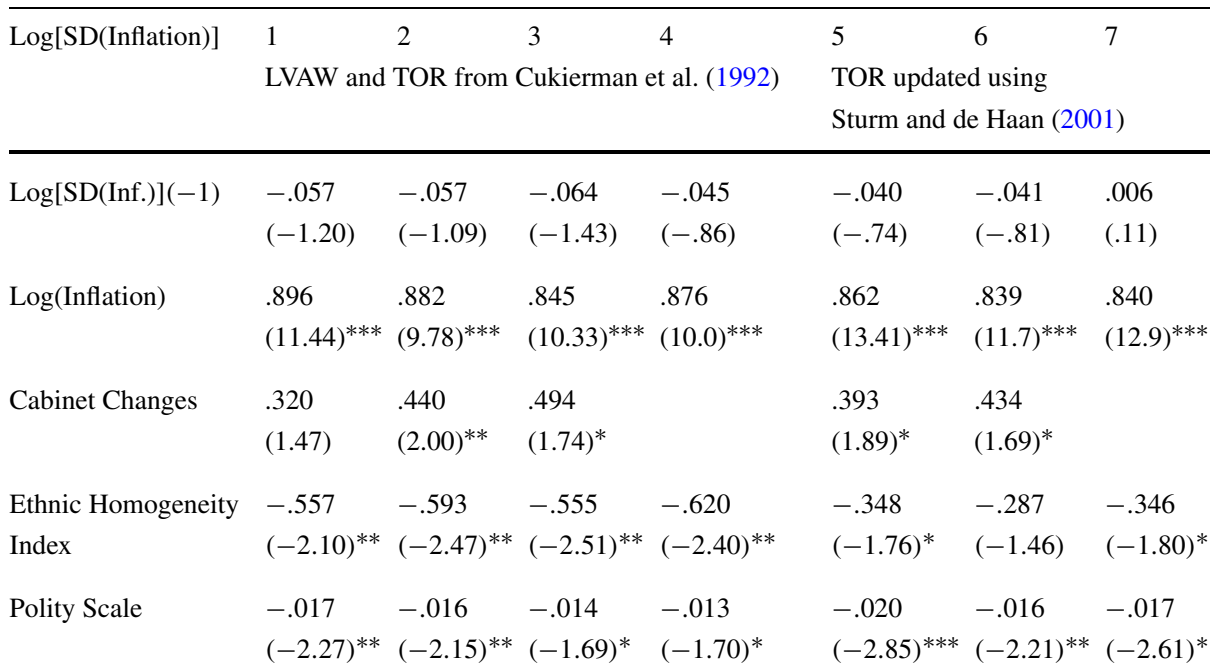

Legal Index of CBI $\quad .142$

(LVAW)

(.25)

Turnover Rate (TOR)

.727

.380

$(3.23)^{* * *}$

$(1.95)^{*}$

Turnover Rate*

.575

$-.419$

(.82)

$(-.62)$

Industrial Countries

.888

.415

Turnover Rate *

$(2.88)^{* * *}$

$(1.82)^{*}$

Cabinet Changes *

.837

.525

$(2.44)^{* *}$

$(1.86)^{*}$

Cabinet Changes *

.110

.044

(.36)

\# Observations

455

455

455

455

\# Countries

58

57

57

57

751

751

725

Sargan test ( $p$-value) $\quad .883$

.910

.457

.766

91

9191

Sources: See Table 1

Notes: - System-GMM estimations for dynamic panel-data models. Sample period: 1960-1999;

- In each estimation, the lagged values two and three periods of the dependent and of the endogenous variables were used as instruments in the first-difference equations and their once lagged firstdifferences were used in the levels equation;

- Two-step results using robust standard errors corrected for finite samples (using Windmeijer's, 2005, correction).

- $t$-statistics are in parenthesis. Significance level at which the null hypothesis is rejected: ${ }^{* *}, 1 \%$; **, $5 \%$, and *, $10 \%$;

- Second order autocorrelation of residuals is always rejected 
to greater inflation volatility in developing countries. These results are consistent with those of Cukierman et al. (1992), who found that legal CBI was related to lower inflation only in industrial countries, while de facto CBI led to lower inflation levels and volatility in developing countries, but not in industrialized countries. Brumm (2006) also found a strong negative relationship between $\mathrm{CBI}$ and inflation in developing countries. ${ }^{14}$

It is also possible that the effects of political instability depend of the degree of independence of the central bank. This hypothesis was tested in column 4, where Cabinet Changes was interacted with dummy variables for high and low turnover rates. ${ }^{15}$ The results indicate that additional cabinet changes lead to higher inflation volatility only when turnover rates are high (when there is low de facto central bank independence). This implies that independent central banks can achieve stable inflation even in the face of political instability.

Since the Cukierman et al. (1992) Turnover Rate (TOR) does not cover the 1990s and is not available for many of the countries included in our sample, we complemented it with the TOR computed for developing countries by Sturm and de Haan (2001), for the 1980s and 1990s. This increased the number of observations from 455 to 751 and the number of countries from 57 to 91 . The results presented in columns 5 to 7 are very similar to those of columns 2 to 4 , although the estimated coefficients and the degree of statistical significance of variables related to $\mathrm{CBI}$ generally are lower.

Another proxy of institutional quality that may affect inflation volatility is the Index of Economic Freedom (Gwartney and Lawson 2002), which Aisen and Veiga (2006) found to be negatively related to inflation levels. Higher values of that index are associated with smaller governments, stronger legal structure and greater security of property rights, access to sound money, greater freedom to exchange with foreigners, and more flexible regulations of credit, labor and business. The Index of Economic Freedom was added to our baseline model in the estimation of column 1 of Table 4. Surprisingly, the coefficient has the wrong sign and is not statistically significant. Since democracy and economic freedom are correlated, this could be due to multicollinearity. Thus, the Polity Scale was excluded from the model of column 2. Although the Index now has the expected negative sign, it is still not statistically significant. This does not mean that economic freedom does not affect inflation volatility. Since it affects inflation levels which, in turn, affect inflation volatility, the result implies that the effects of economic freedom on inflation volatility are indirect and, thus, do not seem go beyond those operating through the level of inflation.

It is also possible that economic freedom affects the relationship between political instability and inflation volatility. That hypothesis was tested in column 3, where Cabinet Changes was interacted with dummy variables for greater and lesser economic freedom. ${ }^{16}$ The results are supportive of the hypothesis, as a greater number of cabinet changes leads to greater inflation volatility only when economic freedom is low. Thus, as happened with central bank independence, better institutional quality dampens the effects of political instability.

In general, relative to developing countries, industrial countries have stronger economic institutions, such as independent central banks and efficient tax systems, rely less on

\footnotetext{
${ }^{14}$ For surveys of empirical studies focusing on the effects of CBI on inflation, see Berger et al. (2001) and Armone et al. (2006). Both surveys conclude that the negative relationship between CBI and inflation is quite robust.

${ }^{15}$ High Turnover Rate takes the value of 1 when the Turnover Rate is greater than 0.33 (central bank governor replaced every 3 years on average), and equals zero otherwise. Low Turnover Rate $=1-$ High Turnover Rate.

${ }^{16}$ High Economic Freedom takes the value of one when the Index of Economic Freedom is greater than 5, and equals zero otherwise. Low Economic Freedom $=1$ - High Economic Freedom.
} 
Table 4 Inflation volatility, economic freedom and industrialization

\begin{tabular}{|c|c|c|c|c|}
\hline $\log [\mathrm{SD}$ (Inflation) $]$ & 1 & 2 & 3 & 4 \\
\hline $\log [\operatorname{SD}(\operatorname{Inf})].(-1)$ & $\begin{array}{l}.018 \\
(.43)\end{array}$ & $\begin{array}{l}.009 \\
(.19)\end{array}$ & $\begin{array}{l}.007 \\
(.12)\end{array}$ & $\begin{array}{l}-.003 \\
(-.07)\end{array}$ \\
\hline $\log$ (Inflation) & $\begin{array}{l}.915 \\
(12.2)^{* * *}\end{array}$ & $\begin{array}{l}.895 \\
(11.4)^{* * *}\end{array}$ & $\begin{array}{l}.773 \\
(9.24)^{* * *}\end{array}$ & $\begin{array}{l}.805 \\
(13.9)^{* * *}\end{array}$ \\
\hline Cabinet Changes & $\begin{array}{l}.478 \\
(2.77)^{* * *}\end{array}$ & $\begin{array}{l}.463 \\
(2.56)^{* *}\end{array}$ & & \\
\hline Ethnic Homogeneity Index & $\begin{array}{l}-.358 \\
(-2.22)^{* *}\end{array}$ & $\begin{array}{l}-.480 \\
(-2.89)^{* * *}\end{array}$ & $\begin{array}{l}-.372 \\
(-1.69)^{*}\end{array}$ & $\begin{array}{l}-.316 \\
(-1.80)^{*}\end{array}$ \\
\hline Polity Scale & $\begin{array}{l}-.019 \\
(-2.37)^{* *}\end{array}$ & & & $\begin{array}{l}-.013 \\
(-2.44)^{* *}\end{array}$ \\
\hline Index of Economic Freedom & $\begin{array}{l}.023 \\
(.33)\end{array}$ & $\begin{array}{l}-.040 \\
(-.64)\end{array}$ & & \\
\hline Cabinet Changes * & & & .124 & \\
\hline High Economic Freedom & & & $(.43)$ & \\
\hline Cabinet Changes * & & & 1.082 & \\
\hline Low Economic Freedom & & & $(2.77)^{* * *}$ & \\
\hline Cabinet Changes * & & & & -.028 \\
\hline Industrial Countries & & & & $(-.10)$ \\
\hline Cabinet Changes * & & & & .796 \\
\hline Developing Countries & & & & $(3.49)^{* * *}$ \\
\hline \# Observations & 766 & 766 & 678 & 1070 \\
\hline \# Countries & 109 & 109 & 109 & 135 \\
\hline Sargan test ( $p$-value) & .773 & .731 & .248 & .493 \\
\hline
\end{tabular}

Sources: See Table 1

Notes: - System-GMM estimations for dynamic panel-data models. Sample period: 1960-1999;

- In each estimation, the lagged values two and three periods of the dependent and of the endogenous variables were used as instruments in the first-difference equations and their once lagged firstdifferences were used in the levels equation;

- Two-step results using robust standard errors corrected for finite samples (using Windmeijer's, 2005, correction).

- $t$-statistics are in parenthesis. Significance level at which the null hypothesis is rejected: ${ }^{* *}, 1 \%$; **, $5 \%$, and ${ }^{*}, 10 \%$;

- Second order autocorrelation of residuals is always rejected

seigniorage revenues (see Aisen and Veiga 2005) and have more stable economic policies (see Fatás and Mihov 2005). Thus, one would expect political instability to have greater effects on inflation volatility in developing countries. The results shown in column 4 support this hypothesis, as Cabinet Changes are associated with greater inflation volatility in developing countries, but not in industrial countries. 
Table 5 presents the results of robustness tests which consist of adding to the baseline model of column 2 of Table 2 economic variables which may affect inflation volatility. The first is the log of Real GDP per capita (PWT), which we expect to have a negative impact on inflation volatility, since as argued above, richer and more industrialized countries generally have stronger economic institutions. The results shown in column 1 are consistent with this hypothesis, as $\log ($ Real GDP per capita) has a negative and statistically significant coefficient. Aisen and Veiga (2006) showed that GDP per capita growth affected inflation. In column 2, we test the hypothesis that more volatile growth, which can result from greater incidence of shocks to the economy, leads to greater inflation volatility. We find support for this hypothesis, as the coefficient on growth volatility is positive and statistically significant. ${ }^{17}$

Greater volatility of external shocks could also lead to higher inflation volatility. In column 3, we add the standard deviation of GDP growth of trading partners (GND-WB), which has the expected positive sign, indicating that more volatile growth abroad leads to greater inflation volatility. Then, in column 4, we included the standard deviation of Real Overvaluation (GDN-WB) of the exchange rate. The results confirm our prior that more volatile real exchange rates lead to higher inflation volatility. The volatility of the Change in oil prices (IFS-IMF) has a positive and weakly statistically significant coefficient in column 5, indicating that external shocks originated in oil markets may affect inflation volatility at home. We expect higher US Treasury Bill rates to lead to greater costs of external financing and induce greater reliance on seigniorage revenues and, consequently, greater inflation levels and volatility. The results shown in column 6 are consistent with this hypothesis.

The exchange rate regime could also play a role, as fixed rates are expected to restrict discretionary monetary policy and, thus, reduce inflation volatility. The Levy-Yeyati and Sturzenegger (2003) exchange rate regime indicator, which varies from 1 (flexible rates) to 5 (fixed rates), is included in the model of column 7 , but is not statistically significant. ${ }^{18}$

Trade openness is accounted for in column 8, in which we include $\log [\operatorname{Trade}(\% G D P)]$, taken from WDI-WB. According to Bowdler and Malik (2005), trade openness reduces inflation volatility by limiting the reliance on seigniorage revenues and by shifting consumption towards goods with stable terms of trade. Granato et al. (2006) conjecture that, if openness leads to a more aggressive inflation-stabilizing monetary policy, there should be a negative relationship between openness and the variance of inflation. The results shown in column 6 are consistent with the above-mentioned hypotheses and with the empirical results obtained in the referred studies.

Finally, in column 9 we add the log of the standard deviation of the growth rate of $M 2$ (IFS-IMF) to the model. This variable is highly statistically significant, the estimated coefficients of Cabinet Changes and Ethnic Homogeneity Index are considerably smaller than in the baseline model (see column 2 of Table 2), and the Polity Scale is no longer statistically significant. These results indicate that the effect of political and institutional variables on inflation volatility operate through more volatile money growth.

It is worth noting that the results regarding the variables included in the baseline model are practically the same across the nine specifications shown in Table 5. That is, regardless of the economic variables that are entered, our conclusions concerning the effects of political instability, social polarization and democracy on inflation volatility remain the same.

In the estimations of Table 6, we analyzed the sensitivity of the results concerning the baseline model to alternative specifications and samples: static model (column 1); model

${ }^{17}$ Real GDP per capita and the volatility of real GDP growth were treated as endogenous variables.

${ }^{18}$ The same result is reported for inflation levels by Aisen and Veiga (2006). 


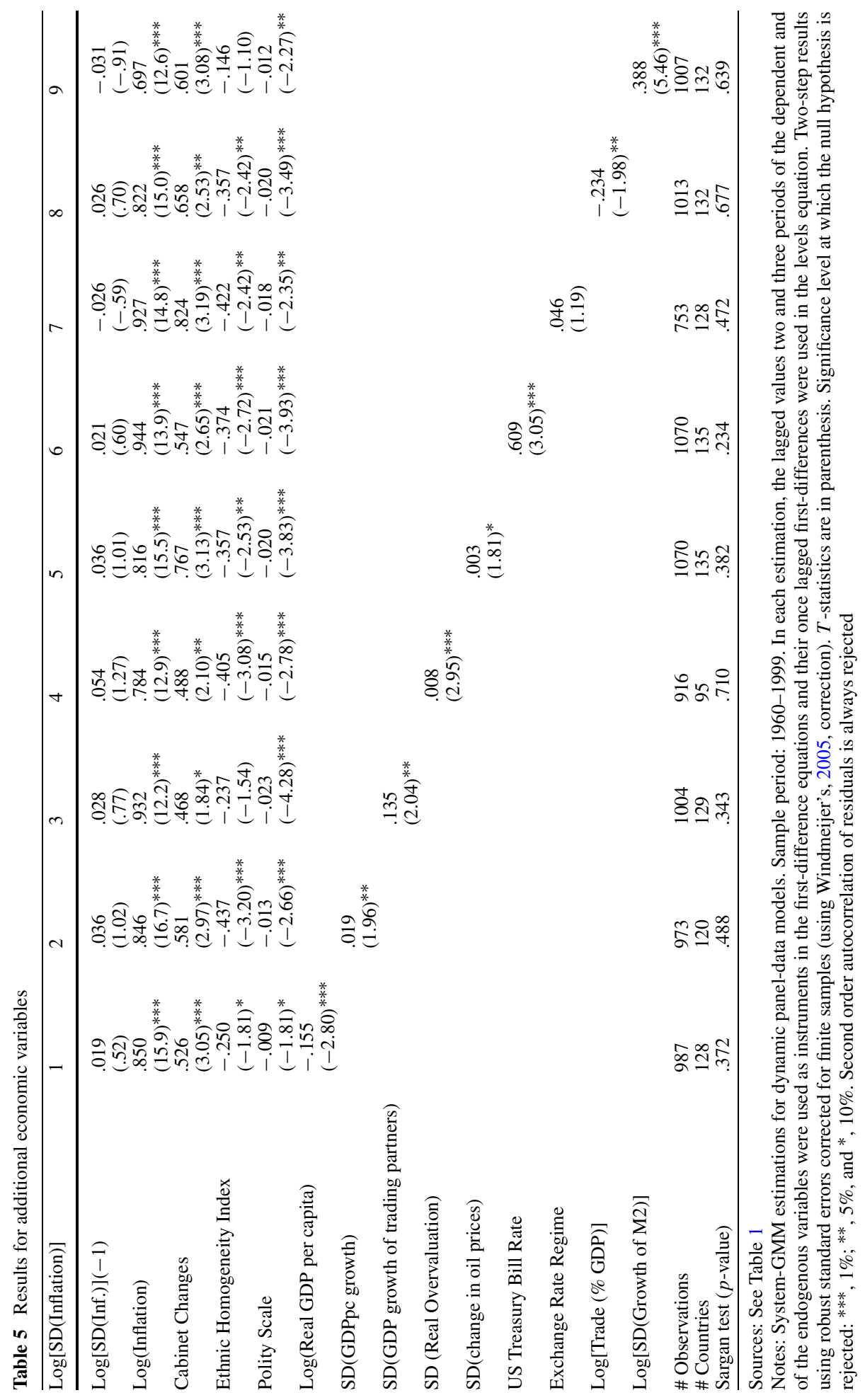


Table 6 Sensitivity analysis

\begin{tabular}{|c|c|c|c|c|c|}
\hline $\log [\mathrm{SD}$ (Inflation) $]$ & $\begin{array}{l}1 \\
\text { Static model }\end{array}$ & $\begin{array}{l}2 \\
\text { Regional } \\
\text { dummies }\end{array}$ & $\begin{array}{l}3 \\
\text { Developing } \\
\text { countries }\end{array}$ & $\begin{array}{l}4 \\
\text { All except } \\
\text { Latin America }\end{array}$ & $\begin{array}{l}5 \\
\text { Inflation } \\
<1000 \%\end{array}$ \\
\hline $\log [\operatorname{SD}($ Inflation $)](-1)$ & & $\begin{array}{l}.013 \\
(.33)\end{array}$ & $\begin{array}{l}.021 \\
(.57)\end{array}$ & $\begin{array}{l}.034 \\
(.98)\end{array}$ & $\begin{array}{l}-.015 \\
(-.43)\end{array}$ \\
\hline $\log$ (Inflation) & $\begin{array}{l}.847 \\
(17.62)^{* * *}\end{array}$ & $\begin{array}{l}.824 \\
(14.59)^{* * *}\end{array}$ & $\begin{array}{l}.833 \\
(13.88)^{* * *}\end{array}$ & $\begin{array}{l}.739 \\
(11.57)^{* * *}\end{array}$ & $\begin{array}{l}.778 \\
(13.56)^{* * *}\end{array}$ \\
\hline Cabinet Changes & $\begin{array}{l}.559 \\
(2.39)^{* *}\end{array}$ & $\begin{array}{l}.738 \\
(3.56)^{* * *}\end{array}$ & $\begin{array}{l}.702 \\
(3.26)^{* * *}\end{array}$ & $\begin{array}{l}.858 \\
(4.25)^{* * *}\end{array}$ & $\begin{array}{l}.786 \\
(3.29)^{* * *}\end{array}$ \\
\hline Ethnic Homogeneity Index & $\begin{array}{l}-.475 \\
(-3.14)^{* * *}\end{array}$ & $\begin{array}{l}-.430 \\
(-2.90)^{* * *}\end{array}$ & $\begin{array}{l}-.178 \\
(-1.12)\end{array}$ & $\begin{array}{l}-.524 \\
(-3.36)^{* * *}\end{array}$ & $\begin{array}{l}-.405 \\
(-2.74)^{* * *}\end{array}$ \\
\hline Polity Scale & $\begin{array}{l}-.019 \\
(-3.18)^{* * *}\end{array}$ & $\begin{array}{l}-.015 \\
(-2.78)^{* * *}\end{array}$ & $\begin{array}{l}-.014 \\
(-2.55)^{* * *}\end{array}$ & $\begin{array}{l}-.025 \\
(-3.95)^{* * *}\end{array}$ & $\begin{array}{l}-.021 \\
(-3.98)^{* * *}\end{array}$ \\
\hline Africa & & $\begin{array}{l}.160 \\
(1.30)\end{array}$ & & & \\
\hline Eastern Europe & & $\begin{array}{l}.288 \\
(1.60)\end{array}$ & & & \\
\hline Middle East & & $\begin{array}{l}.333 \\
(1.87)^{*}\end{array}$ & & & \\
\hline Western Hemisphere & & $\begin{array}{l}.199 \\
(1.73)^{*}\end{array}$ & & & \\
\hline Other Countries & & $\begin{array}{l}.706 \\
(2.90)^{* * *}\end{array}$ & & & \\
\hline \# Observations & 1185 & 1070 & 842 & 841 & 1061 \\
\hline \# Countries & 142 & 135 & 116 & 114 & 134 \\
\hline Sargan test ( $p$-value) & .193 & .400 & .475 & .406 & .341 \\
\hline
\end{tabular}

Sources: See Table 1

Notes: - System-GMM estimations for dynamic panel-data models. Sample period: 1960-1999;

- The dependent variable, $\log ($ Inflation) and Cabinet Changes were treated as endogenous. Their lagged values two and three periods ( 2 to 5 periods in the static model) were used as instruments in the first-difference equations and their once lagged first-differences were used in the levels equation;

- Two-step results using robust standard errors corrected for finite samples (using Windmeijer's, 2005, correction).

- $t$-statistics are in parenthesis. Significance level at which the null hypothesis is rejected: ***, $1 \%$; **, $5 \%$, and *, $10 \%$;

- Second order autocorrelation of residuals is always rejected

that includes regional dummies (column 2); sample including only the developing countries (column 3); sample excluding Latin American countries (column 4); and sample excluding observations for which the inflation rate was equal to or greater than $1000 \%$ (column 5). The results are practically the same as those of column 2 of Table 2 (the baseline model); ex- 
cept that the Ethnic Homogeneity Index is not statistically significant when only developing countries are included in the sample (column 3).

Finally, in the estimations of Table 7, four proxies for political instability were entered into the baseline model, as alternatives to Cabinet Changes, and regressions also were run on a sample of 5-year consecutive and non-overlapping time periods. Column 1 presents the results of the baseline model for samples of 3-year and 5-year periods. Then, in column 2, Cabinet Changes was replaced with Government Crises, defined as rapidly developing situations that threatened the downfall of the government (CNTS). Although this variable is not statistically significant for 3-year periods, it is so for 5-year periods. ${ }^{19}$

Considering that political instability is a multi-dimensional phenomenon, eventually not well captured by just one variable, we constructed three alternative indexes of political instability by applying principal components analysis. ${ }^{20}$ The variables (all from the CNTS) used to define each index were:

- P.I. Index 1: Assassinations, Cabinet Changes, Constitutional Changes, Coups, Executive Changes, Government Crises, and Revolutions.

- P.I. Index 2: Assassinations, Constitutional Changes, Coups, Government Crises, and Revolutions (following Woo 2003).

- P.I. Index 3: Cabinet Changes, Executive Changes, and Government Crises.

Columns 3 to 5 present the results for these 3 indexes of political instability, which are always statistically significant, with the expected positive signs. The results are very similar to those of the baseline model and, thus, support the hypothesis that higher political instability, higher social polarization and less democracy lead to higher inflation volatility.

\section{Conclusions}

Using the system-GMM estimator for linear dynamic panel data models on a sample covering 160 countries, analyzed in the period from 1960 to 1999, this paper finds that higher degrees of political instability and social polarization, less democracy, and lower institutional quality, such as lack of central bank independence, lead to more volatile inflation rates. We clearly show that those variables are important determinants of inflation volatility, and have sizeable direct effects, which go beyond their indirect effects operating through seigniorage and inflation levels already documented in the literature (see Aisen and Veiga 2006, for inflation levels, and Cukierman et al. 1992, and Aisen and Veiga 2005, for seigniorage revenues). Our results concerning the strong positive relationship between inflation levels and volatility are also consistent with previous findings (see, among others, Fischer et al. 2002; Granato et al. 2006; and Bowdler and Malik 2005).

Another contribution to the literature is the identification of circumstances under which greater political instability leads to higher inflation volatility. Our results indicate that this positive relationship is present for low degrees of de facto central bank independence (high turnover rate of central bank presidents) and economic freedom, as well as in developing

\footnotetext{
${ }^{19}$ It is also statistically significant for samples of four- or eight-year periods (results available upon request).

${ }^{20}$ This technique for data reduction describes linear combinations of the variables that contain most of the information. It analyzes the correlation matrix, and the variables are standardized to have mean zero and standard deviation of 1 at the outset. Then, for each of the three groups of variables, the first component identified, the linear combination with greater explanatory power was used as the political instability index.
} 
Table 7 Alternative proxies of political instability and time periods

\begin{tabular}{|c|c|c|c|c|c|}
\hline $\log [\operatorname{SD}($ Inflation $)]$ & $\begin{array}{l}1 \\
\text { Cabinet } \\
\text { Changes }\end{array}$ & $\begin{array}{l}2 \\
\text { Government } \\
\text { Crises }\end{array}$ & $\begin{array}{l}3 \\
\text { Political } \\
\text { Instability } \\
\text { Index } 1\end{array}$ & $\begin{array}{l}4 \\
\text { Political } \\
\text { Instability } \\
\text { Index } 2\end{array}$ & $\begin{array}{l}5 \\
\text { Political } \\
\text { Instability } \\
\text { Index } 3\end{array}$ \\
\hline \multicolumn{6}{|l|}{3 -year periods } \\
\hline $\log [\operatorname{SD}($ Inflation $)](-1)$ & $\begin{array}{l}.029 \\
(.79)\end{array}$ & $\begin{array}{l}.017 \\
(.46)\end{array}$ & $\begin{array}{l}.023 \\
(.69)\end{array}$ & $\begin{array}{l}.019 \\
(.52)\end{array}$ & $\begin{array}{l}.031 \\
(.88)\end{array}$ \\
\hline $\log ($ Inflation $)$ & $\begin{array}{l}.824 \\
(15.3)^{* * *}\end{array}$ & $\begin{array}{l}.833 \\
(16.5)^{* * *}\end{array}$ & $\begin{array}{l}.856 \\
(16.5)^{* * *}\end{array}$ & $\begin{array}{l}.852 \\
(16.0)^{* * *}\end{array}$ & $\begin{array}{l}.841 \\
(15.6)^{* * *}\end{array}$ \\
\hline $\begin{array}{l}\text { Proxy of Political Instability } \\
\text { (see column heading) }\end{array}$ & $\begin{array}{l}.792 \\
(3.38)^{* * *}\end{array}$ & $\begin{array}{l}.093 \\
(.64)\end{array}$ & $\begin{array}{l}.165 \\
(2.45)^{* *}\end{array}$ & $\begin{array}{l}.231 \\
(3.00)^{* * *}\end{array}$ & $\begin{array}{l}.327 \\
(3.10)^{* * *}\end{array}$ \\
\hline Ethnic Homogeneity Index & $\begin{array}{l}-.380 \\
(-2.59)^{* * *}\end{array}$ & $\begin{array}{l}-.354 \\
(-2.33)^{* *}\end{array}$ & $\begin{array}{l}-.328 \\
(-1.98)^{* *}\end{array}$ & $\begin{array}{l}-.344 \\
(-2.30)^{* *}\end{array}$ & $\begin{array}{l}-.451 \\
(-2.98)^{* * *}\end{array}$ \\
\hline Polity Scale & $\begin{array}{l}-.020 \\
(-3.74)^{* * *}\end{array}$ & $\begin{array}{l}-.020 \\
(-3.81)^{* * *}\end{array}$ & $\begin{array}{l}-.014 \\
(-2.38)^{* *}\end{array}$ & $\begin{array}{l}-.018 \\
(-3.24)^{* * *}\end{array}$ & $\begin{array}{l}-.024 \\
(-4.80)^{* * *}\end{array}$ \\
\hline $\begin{array}{l}\text { \# Observations } \\
\text { \# Countries } \\
\text { Sargan test ( } p \text {-value) }\end{array}$ & $\begin{array}{l}1070 \\
135 \\
.378\end{array}$ & $\begin{array}{l}1075 \\
135 \\
.160\end{array}$ & $\begin{array}{l}1070 \\
135 \\
.223\end{array}$ & $\begin{array}{l}1069 \\
135 \\
.252\end{array}$ & $\begin{array}{l}1069 \\
135 \\
.366\end{array}$ \\
\hline \multicolumn{6}{|l|}{ 5-year periods } \\
\hline $\log [\operatorname{SD}($ Inflation $)](-1)$ & $\begin{array}{l}.089 \\
(1.58)\end{array}$ & $\begin{array}{l}.102 \\
(1.77)^{*}\end{array}$ & $\begin{array}{l}.073 \\
(1.28)\end{array}$ & $\begin{array}{l}.076 \\
(1.39)\end{array}$ & $\begin{array}{l}.102 \\
(2.03)^{* *}\end{array}$ \\
\hline $\log ($ Inflation $)$ & $\begin{array}{l}.899 \\
(11.2)^{* * *}\end{array}$ & $\begin{array}{l}.747 \\
(7.43)^{* * *}\end{array}$ & $\begin{array}{l}.856 \\
(9.25)^{* * *}\end{array}$ & $\begin{array}{l}.826 \\
(8.55)^{* * *}\end{array}$ & $\begin{array}{l}.783 \\
(8.89)^{* * *}\end{array}$ \\
\hline $\begin{array}{l}\text { Proxy of Political Instability } \\
\text { (see column heading) }\end{array}$ & $\begin{array}{l}.548 \\
(1.77)^{*}\end{array}$ & $\begin{array}{l}.706 \\
(3.07)^{* * *}\end{array}$ & $\begin{array}{l}.178 \\
(1.92)^{*}\end{array}$ & $\begin{array}{l}.273 \\
(2.41)^{* *}\end{array}$ & $\begin{array}{l}.457 \\
(2.92)^{* * *}\end{array}$ \\
\hline Ethnic Homogeneity Index & $\begin{array}{l}-.332 \\
(-2.02)^{* *}\end{array}$ & $\begin{array}{l}-.460 \\
(-2.52)^{* *}\end{array}$ & $\begin{array}{l}-.312 \\
(-1.70)^{*}\end{array}$ & $\begin{array}{l}-.413 \\
(-2.24)^{* *}\end{array}$ & $\begin{array}{l}-.508 \\
(-3.34)^{* * *}\end{array}$ \\
\hline Polity Scale & $\begin{array}{l}-.021 \\
(-3.38)^{* * *}\end{array}$ & $\begin{array}{l}-.027 \\
(-4.41)^{* * *}\end{array}$ & $\begin{array}{l}-.018 \\
(-3.44)^{* * *}\end{array}$ & $\begin{array}{l}-.023 \\
(-4.18)^{* * *}\end{array}$ & $\begin{array}{l}-.034 \\
(-5.01)^{* * *}\end{array}$ \\
\hline \# Observations & 642 & 645 & 642 & 642 & 642 \\
\hline \# Countries & 132 & 132 & 132 & 132 & 132 \\
\hline Sargan test ( $p$-value) & .176 & .167 & .172 & .158 & .235 \\
\hline
\end{tabular}

Sources: - See Table 1

Notes: - System-GMM estimations for dynamic panel-data models. Sample period: 1960-1999;

- The dependent variable, $\log$ (Inflation) and the Proxy of Political Instability (indicated in the column headings) were treated as endogenous. Their lagged values two and three periods were used as instruments in the first-difference equations and their once lagged first-differences were used in the levels equation;

- Two-step results using robust standard errors corrected for finite samples (using Windmeijer's, 2005, correction).

- $t$-statistics are in parenthesis. Significance level at which the null hypothesis is rejected: ***, $1 \%$; **, $5 \%$, and *, $10 \%$;

- Second order autocorrelation of residuals is always rejected 
countries. But, when central bank independence or economic freedom are high, or in industrial countries, political instability does not seem to affect inflation volatility. Thus, these results imply that the relationship holds only for low levels of institutional quality. It is also worth noting that our results indicate that de facto central bank independence leads to lower inflation volatility in developing countries, but not in industrial countries, which confirms the results of Cukierman et al. (1992).

We believe that this paper's analysis and conclusions are a valuable contribution to academics and policymakers alike. By enhancing economic freedom and reforming institutions, developing countries can create viable mechanisms conducive to long-run price stability. Smaller governments, greater security of property rights, access to sound money, freedom to exchange with foreigners and more flexible markets (all elements of economic freedom), and greater central bank independence constrain the policymakers' monetary and fiscal choices, limiting the ill effects of political instability and of opportunistic or populist policies. Thus, by improving the quality of their institutions, developing countries could go a long way towards long-term economic prosperity.

Acknowledgements The authors wish to thank Carlos Végh, Paolo Mauro, and two anonymous referees for very helpful comments.

\section{References}

Acemoglu, D., Johnson, S., Robinson, J., \& Thaicharoen, Y. (2003). Institutional causes, macroeconomic symptoms: Volatility, crises and growth. Journal of Monetary Economics, 50, 49-123.

Aisen, A., \& Veiga, F. J. (2005). The political economy of seigniorage. IMF Working Paper, 05/175

Aisen, A., \& Veiga, F. J. (2006). Does political instability lead to higher inflation? A panel data analysis. Journal of Money, Credit and Banking, 38(5), 1379-1389.

Arellano, M., \& Bond, S. (1991). Some tests of specification for panel data: Monte Carlo evidence and an application to employment equations. The Review of Economic Studies, 58, $277-297$.

Arellano, M., \& Bover, O. (1995). Another look at the instrumental variable estimation of error-component models. Journal of Econometrics, 68, 29-51.

Armone, M., Laurens, B. J., \& Segalotto, J. F. (2006). Measures of central bank autonomy: Empirical evidence for OECD, developing and emerging market economies. IMF Working Paper, WP/06/228.

Baltagi, B. H. (2001). Econometric analysis of panel data (2nd ed.). Chichester: Wiley.

Barro, R. J., \& Sala-i-Martin, X. (2004). Economic growth (2nd ed.). Cambridge: MIT.

Berger, H., de Haan, J., \& Eijffinger, S. (2001). Central bank independence: An update of theory and evidence. Journal of Economic Surveys, 15, 3-40.

Bleaney, M., \& Fielding, D. (2002). Exchange rate regimes, inflation and output volatility in developing countries. Journal of Development Economics, 68, 233-245.

Blundell, R., \& Bond, S. (1998). Initial conditions and moment restrictions in dynamic panel data models. Journal of Econometrics, 87, 115-143.

Bowdler, C., \& Malik, A. (2005). Oppeness and inflation volatility: Panel data evidence. Nuffield College Economics Working Papers, Ref: 2005-W14.

Brumm, H. J. (2006). The effect of central bank independence on inflation in developing countries. Economics Letters, 90, 189-193.

Cukierman, A., Edwards, S., \& Tabellini, G. (1992). Seignioriage and political instability. American Economic Review, 82(3), 537-555.

Cukierman, A., Webb, S. B., \& Neyapti, B. (1992). Measuring the independence of central banks and its effects on policy outcomes. The Word Bank Economic Review, 6(3), 353-398.

Edison, H. J., Levine, R., Ricci, L., \& Sløk, T. (2002). International financial integration and economic growth. Journal of International Money and Finance, 21, 749-776.

Elder, J. (2004). Another perspective on the effects of inflation uncertainty. Journal of Money, Credit and Banking, 36(5), 911-928.

Fatás, A., \& Mihov, I. (2005). Policy volatility, institutions and economic growth. CEPR Discussion Paper, No. 5388.

Fischer, S., Sahay, R., \& Végh, C. (2002). Modern hyper- and high inflations. Journal of Economic Literature, $X L(3), 837-880$. 
Friedman, M. (1977). Nobel Lecture: Inflation and Unemployment. Journal of Political Economy, 85, 451472.

Fry, M., Julius, D., Mahadeva, L., Roger, S., \& Sterne, G. (2000). Key issues in the choice of monetary policy framework. In S. Mahadeva \& G. Sterne (Eds.), Monetary policy framework in a global context (pp. 1-216). London: Routledge and Bank of England.

Granato, J., Lo, M., \& Sunny-Wong, M. C. (2006). Testing monetary policy intentions in open economies. Southern Economic Journal, 72(3), 730-746.

Gwartney, J., \& Lawson, R. (2002). Economic freedom of the world-2002 Annual report. Vancouver: Fraser Institute.

Holtz-Eakin, D., Newey, W., \& Rosen, H. S. (1988). Estimating vector autoregressions with panel data. Econometrica, 56, 1371-1395.

Judson, R. A., \& Owen, A. L. (1999). Estimating dynamic panel data models: A practical guide for macroeconomists. Economics Letters, 65, 9-15.

Levy-Yeyati, E., \& Sturzenegger, F. (2003). To float or to fix: Evidence on the impact of exchange rate regimes on growth. American Economic Review, 93(4), 1173-1193.

Rogoff, K. (1985). The optimal degree of commitment to an intermediate monetary target. The Quarterly Journal of Economics, 100(4), 1169-1189.

Rother, P. C. (2004). Fiscal policy and inflation volatility. ECB Working Paper, No. 317

Sala-i-Martin, X., Doppelhofer, G., \& Miller, R. I. (2004). Determinants of long-term growth: A Bayesian averaging of classical estimates (BACE) approach. American Economic Review, 94(4), 813-835.

Sturm, J. E., \& de Haan, J. (2001). Inflation in developing countries: Does central bank independence matter? CESifo Working Paper, $\mathrm{n}^{\mathrm{O}} 511$.

Temple, J. (2000). Inflation and growth: Stories short and tall. Journal of Economic Surveys, 14, 395-426.

Windmeijer, F. (2005). A finite sample correction for the variance of linear efficient two-step GMM estimators. Journal of Econometrics, 126, 25-51.

Woo, J. (2003). Economic, political, and institutional determinants of public deficits. Journal of Public Economics, 87, 387-426. 